\title{
Analisis Penyebaran Hunian dengan Menggunakan Metode Nearest Neighbor Analysis
}

\author{
Ahmad Rifad Riadhi*, Muhammad Kasim Aidid, \& Ansari Saleh Ahmar \\ Program Studi Statistika, Fakultas Matematika dan Ilmu Pengetahuan Alam, Universitas Negeri Makassar, Indonesia
}

Keywords: Nearest Neighbor Analysis, Pola Penyebaran

\begin{abstract}
:
Nearest neighbor analysis merupakan sebuah metode analisis yang dapat digunakan untuk menentukan suatu pola penyebaran, apakah berpola seragam (uniform), acak (random), atau mengelompok (cluster). Nearest neighbor analysis dalam perhitungannya mempertimbangkan jarak, jumlah titik lokasi penyebaran, dadn luas wilayah, hasil akhir analisis ini berupa indeks tetangga terdekat $(\mathrm{T})$ yang nilainya berkisar antara 0 sampai 2.15 . Untuk menentukan faktorfaktor yang mempengaruhi pola penyebaran hunian, pada penelitian ini menggunakan analisis korelasi (r). Hasil dari penelitian ini berdasarkan perhitungan nearest neighbor analysis yaitu pola penyebaran hunian di Kota Kendari secara keseluruhan memiliki pola penyebaran yang cenderung berpola acak artinya jarak antara titik-titik penyebaran hunian tidak memiliki jarak yang sama, dan hasil dari perhitungan korelasi diperoleh faktor-faktor yang mempengaruhi pola penyebaran hunian yang cenderung berpola acak. Faktor yang paling berpengaruh dengan hubungan positif yaitu faktor pertumbuhan penduduk, hal ini dapat dilihat pada hasil korelasi dimana faktor pertumbuhan penduduk memiliki nilai korelasi tertinggi yaitu 0.618 dan faktor yang paling berengaruh dengan hubungan negatif yaitu faktor fasilitas Pendidikan hal ini dapat dilihat pada hasil korelasi dimana faktor fasilitas Pendidikan memiliki nilai korelasi negatif tertinggi yaitu -0.526 .
\end{abstract}

\section{Pendahuluan}

Penduduk adalah salah satu bagian penting yang menentukan perkembangan suatu daerah, banyaknya jumlah penduduk suatu wilayah dapat berpengaruh terhadap perkembangan ataupun keberhasilan dari suatu daerah, sehingga dalam hal penyebaran penduduk sangat penting dalam proses pengembagan permukiman yang akan menunjang pembangunan suatu daerah secara berkelanjutan. Analisis spasial adalah suatu cara pendekatan dalam upaya mengelola situasi berbasis wilayah secara geografis yang berhubungan dengan kependudukan, persebaran, lingkungan, perilaku, sosial, ekonomi, ataupun yang lain. Distribusi titik secara spasial merupakan penampakan kejadian dalam suatu ruang. Pengetahuan tentang pola distribusi titik dalam ruang akan memudahkan kita untuk mencari solusi penyebab pola titik dalam ruang tersebut terbentuk, oleh karena itu deteksi pola titik penting untuk diketahui, kita dapat mengetahui pola sebaran titik dengan menggunakan metode nearest neighbor analysis. Nearest neighbor analysis adalah sebuah analisis untuk menentukan suatu pola penyebaran, dengan menggunakan perhitungan nearest neighbor analysis kita dapat mengetahui pola dari penyebaran penduduk apakah berpola seragam (uniform), acak (random), atau kelompok (cluster). Pada hakekatnya, analisis tetangga terdekat digunakan untuk daerah dimana satu pemukiman dengan pemukiman yang lain tidak ada hambatan-hambatan alamiah yang belum dapat teratasi, misalnya jarak antara dua pemukiman yang relatif dekat tetapi dipisahkan oleh jurang atau sungai besar, selain itu untuk pengukuran jarak anatar permukiman dimulai dari pusat permukiman yang ditentukan melalui

\footnotetext{
* Corresponding author.

E-mail address: ahmadriadhi2@gmail.com
} 
penalaran yang objektif. Nearest neighbor analysis akan menghasilkan nilai berkisar dari 0 dampai 2.15 , dimana nilai 0 sampai 0.7 merupaka nilai untuk pola penyebaran mengelompok (cluster), nilai 0.71 sampai 1.4 merupakan nilai untuk pola penyebaran acak (random), dan nilai 1.41 sampai 2.15 merupakan nilai untuk penyebaran seragam (uniform).

\section{Tinjauan Pustaka}

\subsection{Nearest Neighbor Analysis}

John Silk (1979) nearest neighbor analysis merupakan suatu metode dimana jarak sembarang ke tetangga terdekat dalam suatu pola acak $M$ titik. Teknik perhitungan didasarkan pada perbandingan antara rata-rata jarak tetangga terdekat $(\bar{d})$, hasil perhitungan dengan nilai harapan rata-rata jarak tetangga terdekat $(\delta)$, yang diturunkan dari asumsi bahwa pola titik dibangkitkan dari proses acak dan bebas (Aidi, M. N. 2009).

Dalam menggunakan analisis tetangga terdekat harus diperhatikan beberapa langkah sebagai berikut :

1. Menentukan batas wilayah yang akan diselidiki

2. Ubah pola persebaran obyek menjadi pola persebaran titik

3. Berikan nomor urut bagi tiap titik untuk mempermudah analisis

4. Ukur jarak terdekat yaitu jarak pada garis lurus antara satu titik dengan titik lain yang merupakan tetangga terdekatnya dan catat ukuran jarak ini

5. Hitung besar parameter tetangga terdekat atau $\mathrm{T}$ dengan rumus:

Keterangan:

$$
\mathrm{T}=\frac{j u}{j h}
$$

$\mathrm{T}=$ indeks penyebaran tetangga terdekat

$\mathrm{Ju}=$ jarak rata-rata yang diukur antara satu titik dengan titik tetangganya yang terdekat

$\mathrm{Jh}=$ jarak rata-rata yang diperoleh andaikata semua titik mempunyai pola random $=\frac{1}{2 \sqrt{p}}$

$\mathrm{P}=$ kepadatan titik dalam tiap kilometer persegi yaitu jumlah titik $(\mathrm{N})$ dibagi luas wilayah (A)

$\mathrm{T}$ adalah ukuran dari pola jarak yang diamati relatif terhadap pola acak. T berkisar dari 0 samapi 2.15 , dimana akan berpola acak apabila nilai $\mathrm{T}$ berada disekitar 1, berpola kelompok apabila nilai $\mathrm{T}$ lebih kecil dari 1 , dan berpola seragam apabila nilai $\mathrm{T}$ lebih besar dari 1 . Kegunaan dari setiap ukuran jarak akan meningkat jika reliabilitasnya dapat dipastikan. Jika nilai T menunjukkan bahwa populasi tertentu tidak berdistribusi secara acak, signifikasi nilai Ju dan Jh dapat diuji dengan kurva normal. Rumus yang digunakan dalam uji signifikansi ini yaitu:

$$
\begin{gathered}
\mathrm{Z}=\frac{j u-j h}{\sigma_{j h}} \\
\operatorname{dimana} \sigma_{j h}=\frac{0.26136}{\sqrt{N p}}
\end{gathered}
$$

Keterangan :

$\mathrm{Z}=$ standar keragaman dari kurva normal

$\sigma_{j h}=$ kesalahan standar jarak rata - rata ke tetangga terdekat

$\mathrm{p}=$ kepadatan titik

$\mathrm{N}=$ Jumlah pengukuran jarak yang diamati

Singh (1989) membedakan pola pemukiman menjadi tiga kelompok antara lain:

1. Pola permukiman mengelompok biasanya dipengaruhi oleh faktor-faktor permukaan lahan yang datar, lahan subur, curah hujan relatif kurang, kebutuhan akan kerja sama, ikatan sosial, ekonomi, agama, kurangnya keamanan waktu lampau, tipe pertanian, lokasi industri dan mineral.

2. Pola permukiman tersebar biasanya dipengaruhi oleh topografi yang kasar, keanekaragaman kesuburan lahan, curah hujan, air permukiman yang melimpah, keamanan waktu lampau dan suasana kota. 
3. Pola permukiman seragam yaitu pola suatu permukiman dapat dipengaruhi pola oleh lingkungan fisik seperti relief, sumber air, jalur drainase, kondisi lahan, serta kondisi sosial ekonomi, tata guna lahan, rotasi tanaman, prasarana transportasi, komunikasi serta kepadatan penduduk.

\subsection{Korelasi}

Korelasi didefinisikan sebagai hubungan dua peubah atau lebih. Pada analisis korelasi tidak didasarkan pada definisi yang tegas tentang peubah bebas $(\mathrm{X})$ peubah terikat $(\mathrm{Y})$, kedua dapat bertukar tempat dan bersifat acak. Model korelasi mengasumsikan bahwa pada suatu populasi terdapat pasangan nilai X dan $\mathrm{Y}$, keduanya saling berhubungan dan tidak ada yang bersifat pasti.Korelasi adalah istilah statistik yang menyatakan derajat hubungan linier antar variabel. Ada berbagai macam jenis korelasi yaitu Korelasi Product Moment Pearson, Korelasi Rank Spearman, Korelasi Point Serial, Korelasi Biserial, Korelasi Koefisien Kontingensi, dari sekian banyak jenis korelasi yang akan digunakan adalah Korelasi Product Moment Pearson, korelasi ini dipilih karena dalam penelitin ini ingin melihat ada tidaknya hubungan anata pola penyebaran penduduk dengan faktor-faktor apa saja yang mempengaruhi pola tersebut dan karena kedua variabel berskala interval.

Nilai korelasi (r) dapat dihitung dengan rumus:

keterangan:

$$
\mathrm{r}_{\mathrm{xy}}=\frac{n \sum X Y-\left(\sum X\right)\left(\sum Y\right)}{\sqrt{\left\{n \sum X^{2}-\left(\sum X\right)^{2}\right\}\left\{n \sum Y^{2}-\left(\sum Y\right)^{2}\right\}}}
$$

$\mathrm{X}=$ Peubah bebas (kepadatan penduduk, pertumbuhan penduduk,jumlah fasilitas peribadatan, jumlah fasilitas pendidikan, sumlah fasilitas ekonomi, fasilitas kesehatn)

$\mathrm{Y}=$ Peubah terikat (indeks tetangga terekat $(\mathrm{T})$

\section{Metode Penelitian}

Jenis penelitian dilihat dari pendekatan dibagi menjadi dua yaitu : pendekatan kuantitatif dan pendekatan kualitatif. Dalam peneltian ini akan digunakan pendekatan kuantitatif. Pendekatan kuantitatif adalah penelitian yang analisinya lebih fokus pada data-data numerik (angka) yang akan diolah menggunakan metode statistika. Data yang digunakan pada penelitian ini bersumber dari Publikasi Badan Pusat Statistik Kota Kendari Tahun 2015.

Dalam penelitian ini terdapat beberapa peubah yaitu:

\begin{tabular}{lll}
\hline Peubah & Keterangan \\
\hline Y & Indeks Penyebaran Tetangga Terdekat & \\
X1 & Kepadatan Penduduk & \\
X2 & Pertumbuhan Penduduk & \\
X3 & Fasilitas Peribadatan & \\
X4 & Fasilitas Kesehatan & \\
X5 & Jumlah pasar dan toko & \\
X6 & Jumlah fasilitas pendidikan (TK, SD/MI, SLTP/MTs, \\
& SLTA/SMK/MA, Akademi/PT) & \\
\hline
\end{tabular}

Prosedur teknis analisis data:

1. Pembuatyan Peta Wilayah

2. Analisis Pola Penyebaran Hunian

3. Analisis Korelasi 


\section{Hasil dan Pembahasan}

\subsection{Peta Wilayah Kota Kendari}

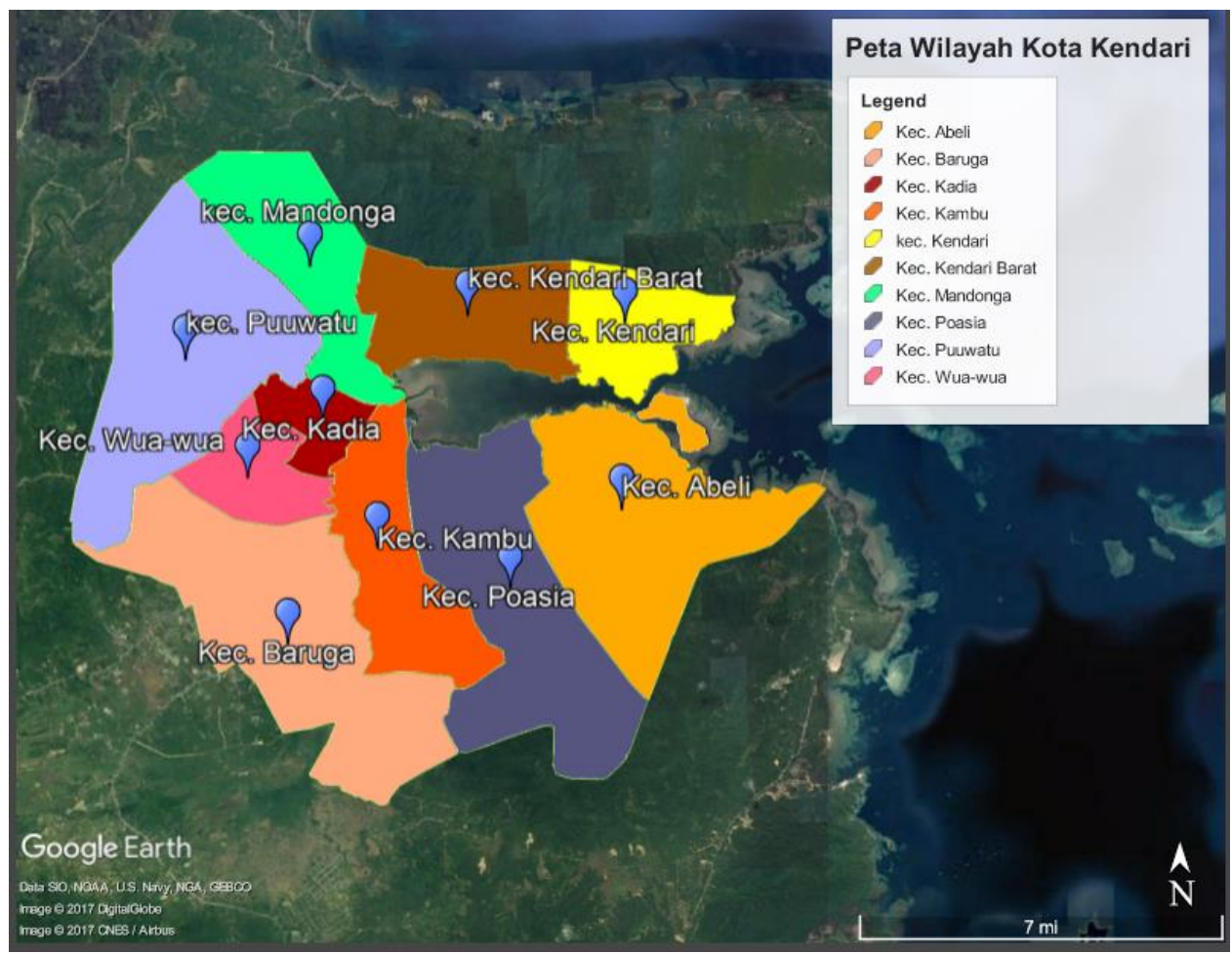

Gambar 1 Peta Wilayah Kota Kendari

Wilayah administrasi Kota Kendari terdiri dari 10 wilayah kecamatan, yaitu kecamatam Mandonga, Kecamatan Baruga, Kecamatan Puuwatu, Kecamatan Kadia, Kecamatan Wua-wua, Kecamatan Poasia, Kecamatan Abeli, Kecamatan Kambu, Kecamatan Kendari, dan Kecamatan Kendari Barat.

\subsection{Pola Penyebaran Hunian Menggunakan Nearest Neighbor Analisis}

Tabel 1 Pola Penyebaran Hunian Kota Kendari

\begin{tabular}{llrrrccl}
\hline No. & Kecamatan & N & \multicolumn{1}{c}{ A } & Ju & Jh & T & Pola \\
\hline 1 & Mandonga & 13 & 23.33 & 0.69 & 0.67 & 1.02 & Acak \\
2 & Baruga & 27 & 49.15 & 0.78 & 0.68 & 1.14 & Acak \\
3 & Puuwatu & 19 & 45.79 & 0.69 & 0.78 & 0.88 & Acak \\
4 & Kadia & 11 & 7.61 & 0.97 & 0.41 & 1.53 & Seragam \\
5 & Wua-wua & 11 & 9.73 & 0.63 & 0.64 & 1.34 & Acak \\
6 & Poasia & 20 & 55.51 & 0.73 & 0.83 & 0.87 & Acak \\
7 & Abeli & 21 & 46.98 & 0.78 & 0.75 & 1.04 & Acak \\
8 & Kambu & 13 & 21.17 & 0.74 & 0.64 & 1.15 & Acak \\
9 & Kendari & 11 & 14.21 & 0.61 & 0.77 & 1.07 & Acak \\
10 & Kendari & 10 & 22.41 & 0.59 & 0.75 & 0.74 & Mengelompok \\
& Barat & & & & & & \\
\hline
\end{tabular}

Sumber:Hasil analisis 
Berdasarkan hasil perhitungan yang didpatkan seperti pada Tabel 1 menunjukkan bahwa di kota Kendari dari 10 kecamatan terdapat ada 1 kecamatan yang berpola seragam yaitu kecamatan Kadia. Kecamatan kadia merupakan kecamatan yang memiliki kepadatan penduduk paling tinggi dan luas wilayah yang paling kecil, kemudian ada 1 kecamatan yang berpola mengelompok yaitu kecamatan Kendari Barat, dilihat dari peta wilayahnya permukiman tersebar mengelompok di area selatan yang dikarenakan kebanyakan wilayah kecamatan kadia merupakan pegunungan, dan ada 8 kecamatan berpola acak yaitu kecamatan Mandonga, Baruga, Puuwatu, Wua-wua, Poasia, Abeli, Kambu, dan Kendari. Dari hasil tersebut dapat dikatakan bahwa secara keseluruhan penyebaran hunian di kota Kendari cenderung memiliki pola acak.

\subsection{Analisis Korelasi}

Tabel 2 Analisis Korelasi

\begin{tabular}{|c|c|c|c|c|c|c|c|}
\hline & & $\mathrm{X} 1$ & $\mathrm{X} 2$ & X3 & $\mathrm{X} 4$ & $\mathrm{X} 5$ & X6 \\
\hline \multirow[t]{2}{*}{$\mathrm{Y}$} & Nilai Korelasi & 0.704 & -0.019 & 0.285 & 0.019 & 0.587 & -0.462 \\
\hline & Uji t & 2.808 & -0.053 & 0.843 & 0.053 & 2.052 & -1.475 \\
\hline
\end{tabular}

Berdasarkan perhitungan korelasi diperoleh nilai korelasi antara indeks tetangga terdekat dengan faktor-faktor penyebaran hunian terdapat 4 faktor yang berhubungan positif dan 2 faktor yang berhubungan negatif.

\section{Kesimpulan}

Berdasarkan hasil penelitian dan pembahasan tentang pola penyenaran hunian dengan menggunakan metode nearest neighbor analysis, maka dapat disimpulkan sebagai berikut:

1. Bedasarkan hasil perhitungan indeks tetangga terdekat disetiap kecamatan di kota Kendari dapat disimpulkan bahwa penyebaran hunian di kota Kendari cenderung memiliki pola acak, yang berarti jarak antara satu lokasi permukiman dengan lokasi permukiman lainnya tidak teratur atau tidak memiliki jarak yang sama.

2. Berdasarkan hasil perhitungan korelasi antara faktor-faktor yang berhubungan dengan pola penyebaran diketahui bahwa terdapat faktor yang memiliki hubungan positif dan beberapa faktor memiliki hubungan negatif

3. Adapun faktor-faktor yang memiliki hubungan positif terhadap pola penyebaran hunian yaitu faktor kepadatan penduduk, fasilitas peribadatan, fasilitas ekonomi, dan fasilitas kesehatan dan untuk faktor-faktor yang memiliki hubungan negatif terhadap pola penyebaran hunian yaitu pertumbuhan penduduk dan faktor fasilatas pendidikan.

\section{References}

Akamagune, E.N. The Nearest Neighbor Analysis, University of Benin, Nigeria

Aidi, M.N. 2009. Perbandingan Deteksi Pola Sebaran Titik Spasial secara Acak dengan Metode Kuadran dan Teteangga Terdekat. Konfigurasi Titik dalam Ruang. Departemen Statistika Institut Pertanian Bogor.

Badan Pusat Statistik Kota Kendari. 2016. Kota Kendari Dalam Angka 2016

Baddeley, A. 2010. Analysing Spatial Point Patterns in R. Australia: CSIRO and University of Western Australia.

Cholil, M. \& Martono, A.D. 2010. Analisis Pola Persebaran Pemukiman di Kabupaten Sragen Propinsi Jawa Tengan. Jurnal Penelitian Sains \& Teknologi, vol.11, No. 2, hal $167-178$

Clark, P.J., \& Evans, F.C. 1954. Distance to Nearest Neighbor as a Measure of Spatial Relationship in Populations. JSTOR Ecology, volume 35, 445-453.

Cornelius, B.O. Nearest Neighbor Analysis, Geography and Regional Planing University of Benin, Nigeria. 
Direktorat Jenderal Anggaran Kementrian Keuangan.2015. Kajian Kependudukan.

Firdayanti, S. 2010. Perkembangan Permukiman Penduduk di Kecamatan Ngamplak Kabupaten Boyolali Tahun 1997 - 2007. Skripsi. Fakuktas Keguruan dan Ilmu Pendidikan Universitas Sebelas Maret Surakarta.

Hudayya, R. 2010. Aplikasi Sistem Informasi Geografis (SIG) Untuk Analisis Pola Sebaran dan Perkembangan Permukiman. Skrisi. Program Studi Manajemen Sumberdaya Lahan Departemen Ilmu Tanah dan Sumberdaya Lahan Fakultas Pertanian Institut Pertanian Bogor.

Hutchinson, J.W. 1986. Nearest Neighbor Analysis of Psychological Space. Psychological Review. Vol 93, No.1, 322.

Martono, A.D. Desember 1996. Kajian Pola Persebaran Permukiman di Kabupaen Klaten Propinsi Jawa Tengah. Forum Geografi Jurnal Fakultas Geografi Universitas Muhammadiyah Surakarta. No 19 Th.X. hal 1 - 19.

Rachman, H.F. 2010. Kajian Pola Spasial Pertumbuhan Kawasan Perumahan dan Permukiman di Kecamatan Limboto Kabupaten Gorontalo. Tesis. Program Pascasarjana Magister Teknik Pembangunan Wilayah dan Kota Universitas Diponegoro Semarang.

Rahayu, Y. 2016. Pemetaan Penyebaran dan Prediksi Jumlah Penduduk Menggunakan Model Geometrik di Wilayah Bandar Lampung WEB-GIS. Skripsi. Jurusan Ilmu Komputer Fakultas Matematika dan Ilmu Pengetahuan Alam Universitas Lampung.

Sangalang, I. \& FredyantonI, F.A. 2014. Pengaruh Kondisi Hunian dan Lingkungan Terhadap Keberlanjutan Permukiman Tepi Sungai Studi Kasus: Kampung Pahandut dan Danau Tundai di Kota Palangka Raya. Jurnal Perspektif Arsitektur. Volume 9, Nomor 2

Saraswati, D.A., Subiyanto, S. \& Wijaya, A.P. Januari 2016. Analisis Perubahan Luas dan Pola Persebaran Permukiman. Jurnal Geodesi Undip. Volume 5, Nomor 1, 155 - 163.

Setyawarman, A. 2009. Pola Sebaran dan Faktor-Faktor yang Mempengaruhi Pemilihan Lokasi Retail Modern (Studi Kasus Kota Surakarta). Tesis. Program Pascasarjana Magister Teknik Pembangunan Wilayah dan Kota Unversitas Diponegoro Semarang.

Syaadah, N. Oktober 2014. Analisis Dampak Pertambahan Penduduk Terhadap Penyerapan Angkatan Kerja. Jurnal Ilmiah Pendidikan Geografi. Vol 2, No.1, hal $61-70$

Tiro, M.A., 2011. Analisis Korelasi dengan Data Kategori. Edisi Kedua. Makassar: Andira Publisher. 